\author{
В.І. Рєзнік ${ }^{1}$, М.М. Постольник ${ }^{1}$, В.М. Мосолов ${ }^{1}$, С.М. Сторожук ${ }^{2}$ \\ ${ }^{2}$ Національний університет оборони Украйни імені Івана Черняховського, Київ \\ ${ }^{1}$ Державний науково-дослідний інститут авіаиії, Київ
}

\title{
АВІАЦІЙНА ТЕХНІКА ЧЕТВЕРТОГО І П'ЯТОГО ПОКОЛІНЬ: ІСТОРІЯ ТА НАПРЯМИ ПОДАЛЬШОГО РОЗВИТКУ
}

\begin{abstract}
У статті розглядаються процеси виникнення і розвитку бойової авіаційної техніки тактичної авіації четвертого і n'ятого поколінь. Висвітлюються причини, щзо спонукали ї̈ виникнення, характерні риси та відмінності. Розглядаються сильні і слабкі сторони тактичних винищувачів різних поколінь, проводиться їх порівняльний аналіз. Автори зробили висновок про те, щзо на сьогодні представлені у світі багатофункиіональні винищувачі п'ятого покоління не повністю задовольняють потреби військовоповітряних сил як через неповну відповідність тактичним вимогам, так $i$ з економічних міркувань. Визначаються напрями подальшого розвитку авіаційної технічки четвертого покоління, щуо не вичерпала свій модернізачійний потенціал та спроможна у середньостроковій перспективі відповідати вимогам сучасності. Наприкіниі статті висуваються пропозищї щодо можливих напрямів оновлення літакового парку тактичної авіачії Повітряних Сил Збройних Сил України.
\end{abstract}

Ключові слова: тактична авіачія; багатофункиіональний винищувач, технологї Stеalth, покоління винищувачів, надманевреність, модернізачія.

\section{Вступ}

Постановка проблеми. Останні двадцять років відзначились суттєвим прогресом у розвитку авіаційної техніки (АТ) тактичної авіації у провідних країнах світу. Цей прогрес проявляється у появі на озброєнні провідних країн світу бойових літаків 5-го покоління. Отже, можна було би зробити висновок, що у найближчі роки ми спостерігатимемо процес заміни літаків попереднього, 4-го покоління новими, як це відбувалось у попередні роки з приходом літаків нової генерації. Проте, цього на сьогодні не відбувається, адже спостерігаються два різноспрямованих процеси: 3 одного боку активні роботи щодо створення новітніх, принципово нових бойових машин i навіть пошукові науково-дослідні роботи щодо вироблення обрису перспективних літаків 6-го покоління, а 3 іншого - не менш активна модернізація машин 4-го покоління, тобто тих, на заміну яким і розроблялись новітні зразки.

На нашу думку, в ситуації, коли літаковий парк авіації Повітряних Сил Збройних Сил (ПС 3С) України потребує негайного i суттєвого оновлення, що для будь-якої країни навіть у мирний час доволі проблематично, вибір раціонального шляху розв'язання цієї проблеми $\epsilon$ вкрай актуальним. Запорукою успішної модернізації вітчизняної авіації $\epsilon$ визначення перспектив подальшого розвитку АТ тактичної авіації, що потребує певного ретроспективного огляду розвитку АТ 4-го і 5-го поколінь.

Отже, виходячи із актуальності теми, автори вважають необхідним висвітлити процес розвитку АТ тактичної упродовж останніх 50-ті років, окреслити основні тенденції та перспективи, а також висловити свій погляд на найбільш раціональний шлях переозброєння авіації ПС ЗС України для приведення їх можливостей до відповідності сучасним і перспективним загрозам, що і $є$ метою статті.

Аналіз останніх досліджень і публікацій. Розвиток АТ 4-го і 5-го поколінь був предметом уваги багатьох вітчизняних та іноземних фахівців у різних галузях науки. Однією із найбільш фундаментальних праць воєнно-історичного характеру була робота відомого радянського воєнного історика авіації В. Бабича "Истребители меняют тактику" [14], що також доступна в Інтернеті. Автор висвітлив низку проблем як технічного, так i тактичного характеру, що призвели до початку на рубежі 1960 - 1970-х років науково-дослідних і дослідноконструкторських робіт щодо створення бойових літаків 4-го покоління. Низка праць українського дослідника А. Харука "ВВС XXI века"[35] та “Боевая авиация XXI века" [34]. Важливим джерелом інформації, на думку авторів, є та, що надається розробниками АТ на своїх офіційних сайтах, перш за все таких корпорацій, як Boeing [1], Lockheed Martin [10], РСК МиГ [28], Сухой [32], що обгрунтовано вважаються світовими 
лідерами у виробництві літаків тактичної авіації, та публікації, розміщені на сайтах, що спеціалізуються на авіаційній проблематиці. Інколи такі матеріали можуть носити рекламний характер, проте аналіз інформації 3 різних джерел, а також особистий службовий досвід автора дозволили виявити серед всього розмаїття публікацій раціональне зерно і прийти до певних висновків.

Після війни в Кореї (1950 - 1953) набули суттєвого прогресу надзвукові літаки тактичної авіації та засоби автоматичного управління винищувачами. Способи ведення повітряного бою розглядались в контексті різкого зростання швидкісних характеристик літаків. При цьому збільшення швидкості призводило до погіршення інших характеристик: перш за все маневреності і швидкості набору висоти. Затвердилась нова концепція багатоцільового тактичного винищувача (винищувача-бомбардувальника), яскравим представником яких можна вважати McDonnellDouglas F-4 Phantom, що поєднував високі ударні можливості з високою швидкістю польоту, що вважалася основним фактором, який обумовлював перевагу у повітрі. Одночасно у 1954 - 1956 рр. відбувались випробування всепогодного перехоплювача Lockheed F-104 Starfighter, оснащеного бортовою радіолокаційною станцією (БРЛС) i автоматизованою системою управління ракетами класу “повітря - повітря”. Тактика перехоплення зводилась до зближення з повітряною ціллю із задньої півсфери за рахунок високої швидкості та ракетної атаки. Ближній груповий маневрений бій вважався таким, що відійшов в історію [13].

При розробленні F-4 американські конструктори виходили із того, що завдяки кращій електроніці, більш компактній, у порівнянні з радянською, та більш потужним i ефективним двигунам, вони досягнуть перевагу у виявленні та взятті на супроводження радянських винищувачів (більш потужна БРЛС) та знищуватимуть їх у дальньому ракетному бою, обстрілюючи противника на відстані, з якої той ледве зможе їх лише виявити. Після знищення у повітрі ворожої авіації ті ж самі $\mathrm{F}-4$ завдаватимуть удари по наземним цілям, маючи потужну БРЛС, підвісні оптико-електронні станції та широку номенклатуру авіаційних керованих і некерованих ракет i бомб. Більш потужні i економічні двигуни дозволяли розміщувати на літаках доволі важке і енергоємне обладнання й значний боєкомплект та забезпечували на середніх і великих висотах надзвукову швидкість. Недоліком такого підходу була певна втрата маневреності, але ближній повітряний бій американцями вважався неактуальним через можливість дальнього вогневого ураження противника, безальтернативного для боротьби зі стратегічними бомбардувальниками та найбільш ймовірного (а скоріш - бажаного) для боротьби 3 тактичною авіацією противника. Такий вид авіаційного озброєння, як автоматичні гармати, вважався атавізмом і їх встановлення не було передбачено [8].

Необхідність оброблення значного обсягу інформації для видачі iї у прийнятному вигляді екіпажу та в систему управління ракети призвели до необхідності їх включення у бортовий прицільно-навігаційний комплекс 3 іншими системами: навігаційними різної фізичної природи (радіотехнічними, анероїднобарометрічними, інерційними тощо), державного розпізнавання, управління зброєю. Комплексне оброблення великого масиву тактичної та навігаційної інформації відбувалось у бортових обчислювальних машинах. Це стало можливим завдяки інтеграції різних інформаційних та виконавчих пристроїв і систем на борту літаканосія у бортовий прицільно-навігаційний комплекс (ПрНК). Характерною особливістю таких ПрНК була наявність у їх складі інформаційних датчиків різної природи, наприклад, стаціонарно встановленої БРЛС, спроможної працювати як по повітряним, так і по наземним цілям та оптико-електронної станції, 3 початку лазерних далекомірів, а згодом - i повноцінних лазерно-телевізійних прицільних систем [24, с. 96 ].

Проте, за результатами війн у В'єтнамі та на Близькому Сході у другий половині 1960-х років стало очевидним, що погляди воєнних теоретиків i авіаконструкторів на обрис тактичних літаків не витримали перевірку практикою реального бойового застосування у різних умовах. 3'ясувалося, що недостатньо маневрені літаки, непідготовлені до ведення маневреного бою в широкому діапазоні висот і швидкостей екіпажі у складній радіоелектронній обстановці не спроможні ані боротись з літаками противника, ані проривати його протиповітряну оборону (ППО) та уражати наземні цілі 3 достатньою результативністю. До таких висновків прийшли як американські, так i радянські фахівці практично одночасно. Ціною нехтування базових принципів воєнного мистецтва (зокрема органічного поєднання вогню і маневру) стали невірні рішення у визначенні спрямованості воєнно-технічної політики, за що довелось платити життям людей та втратами дорогої авіаційної техніки. Слід також враховувати значний прогрес у розвитку засобів ППО та радіоелектронної боротьби. За результатами воєнних конфліктів на озброєння провідних країн 
світу стали прийматись багатоканальні зенітноракетні комплекси 3 високою вогневою продуктивністю, завадостійкістю та маневреністю, що також висунуло нові вимоги до майбутніх авіаційних ударних комплексів тактичної авіації.

Постала проблема створення авіаційних комплексів тактичної авіації, спроможних однаково успішно вести груповий повітряний бій, зокрема й маневрений, на малих, середніх i великих дистанціях, у складній завадовій обстановці та завдавати удари по широкій номенклатурі наземних i надводних цілей в умовах війни, що ведеться як конвенційною, так i зброєю масового ураження. Нові авіаційні комплекси повинні були будуватись за відкритою архітектурою, бути максимально простими в експлуатації інженерно-технічним складом та управлінні у польоті, мати значний модернізаційний потенціал. У системі управління літаком та озброєнням передбачалось широке застосування цифрового оброблення інформації. Високі вимоги висувались до маневрених характеристик, спроможності застосовувати зброю при енергійному маневруванні літака у бою, однаково успішно виконувати завдання у всьому діапазоні висот i швидкостей, бути придатними за економічними показниками до масового виробництва.

На нашу думку, значною проблемою, 3 якою зіткнулись у провідних країнах під час створення нових авіаційних комплексів, було задоволення економічних обмежень, адже від покоління до покоління вартість нової авіаційної техніки постійно і суттєво зростала (рис. 1).

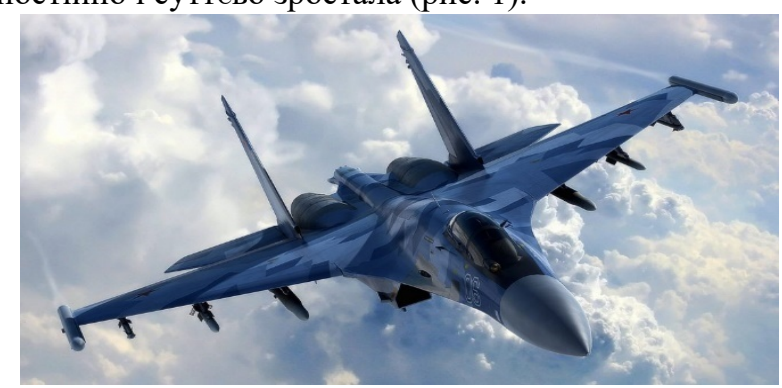

Рис. 2 Су-27 (СРСР).

Джерело [22].

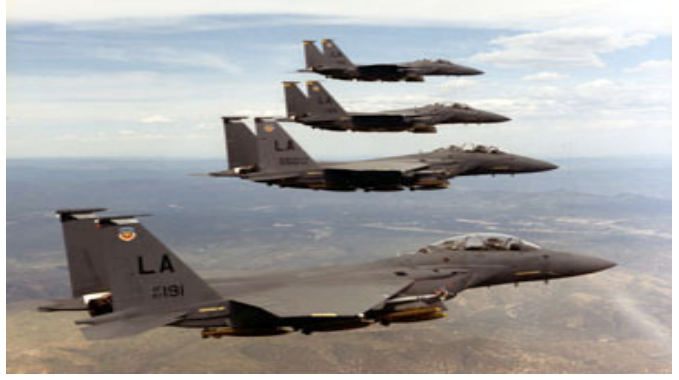

Рис. 4. McDonnellDouglasF-15 Eagle (США). Джерело [5].

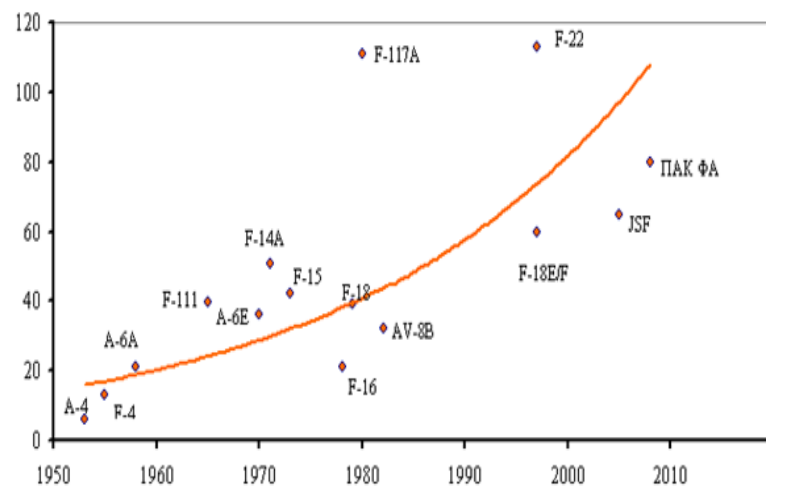

Рис. 1. Зміна вартості одного літака тактичної (палубної) авіації в млн. дол. США за роками.

Джерело: [26].

За досвідом війни у В'єтнамі було зроблено висновок, що авіаційний комплекс тактичної авіації повинен бути збалансованим за своїми характеристиками, поєднувати в собі потужну інформаційну підсистему, чисельне i різноманітне озброєння, високі маневрені характеристики, адаптивність до виконання різних бойових завдань. Виходячи із цього, у провідних авіаційних державах світу був обраний курс на створення багатофункціональних авіаційних платформ, на базі яких створювалась ціла лінійка бойових літаків. Для виконання всього комплексу бойових завдань в СРСР та США почалося створення модельного ряду на основі важкого і легкого винищувачів, що було реалізовано у проєктах таких видатних машин, як Су-27 (рис. 2), МиГ-29 (рис. 3), F-15 (рис. 4) [5], F-16 (рис. 5) [6].

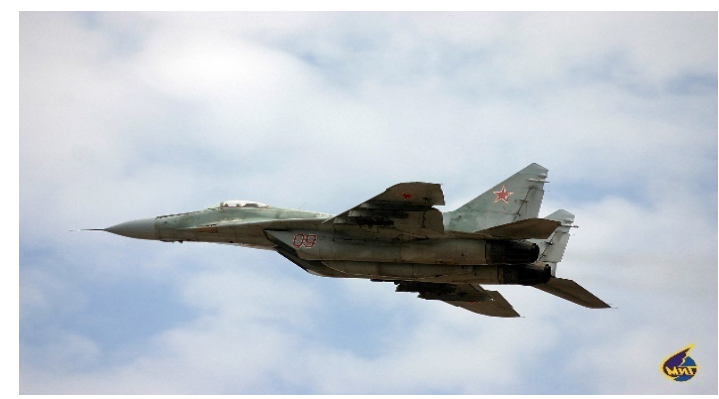

Рис. 3МиГ-29 (СРСР). Джерело [21].

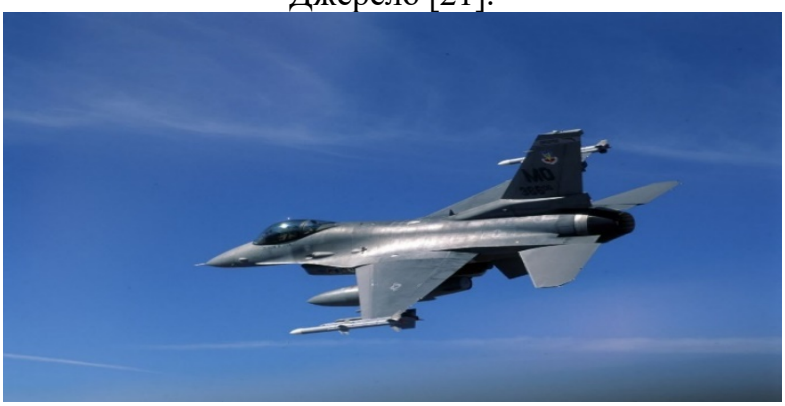

Рис. 5. General Dynamics F-16 FightingFalcon (США). Джерело [6]. 


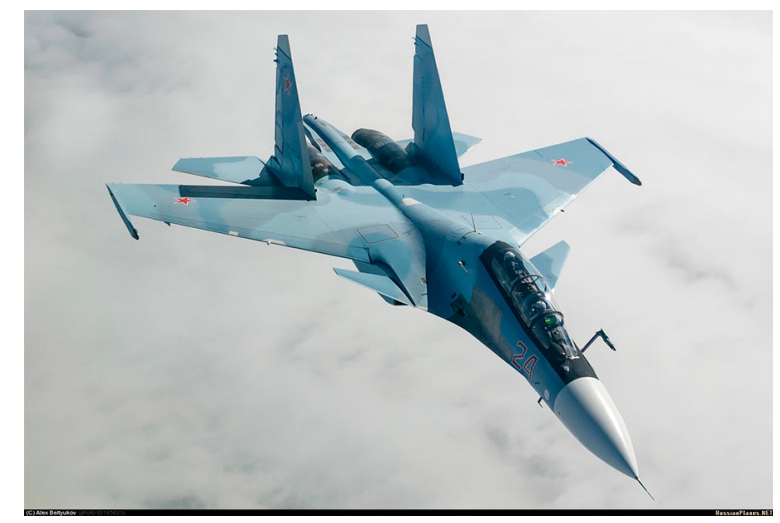

Рис. 6. Су-30.

Джерело [23].

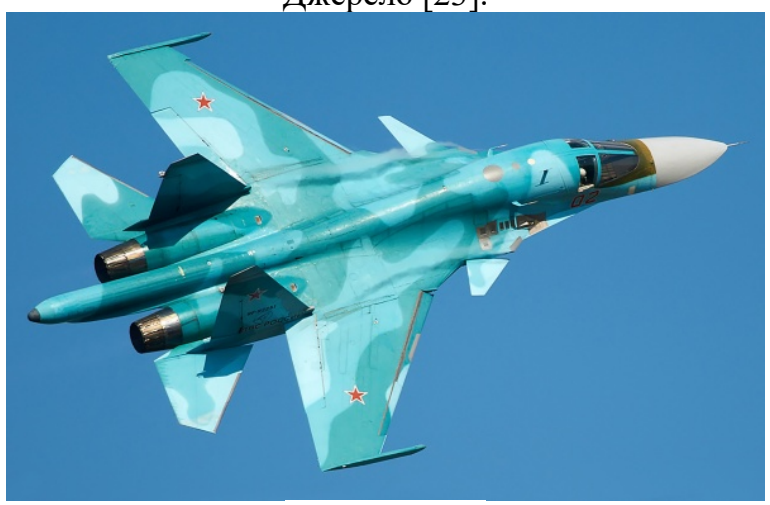

Pис. 8. Су-34.

Джерело [30].

Відповідаючи наведеним вище вимогам, ці машини й стали такими платформами, достатньо згадати, як приклад, радянський Су-27, на базі якого у подальшому були створені багатофункціональний винищувач Су-30 (рис. 6), винищувач Су-35С (рис. 7), бомбардувальник Су-34 (рис. 8), палубний винищувач Су-33 (рис. 9).

Аналогічна склалася доля і американського “однокласника". Так, на платформі F-15 були згодом створені модифікації винищувача завоювання панування у повітрі, двомісного винищувача-бомбардувальника. У 1980 -х роках існував навіть проєкт створення на базі F-15 винищувача космічних об'єктів на низьких орбітах, озброєного ракетою класу “повітря космос" ASM-135A ASAT [11]. За повідомленнями відкритої преси аналогічні проєкти наразі реалізовуються в Росії та Китаї, проте про їх результати говорити ще зарано [33].

Перевага машин 4-го покоління вперше була продемонстрована під час арабо-ізраїльської війни 1982 року. Під час повітряних боїв між сирійськими винищувачами МиГ-21, МиГ-23 та МиГ-25 проти ізраїльських F-15I, що отримували інформацію про повітряну обстановку від літаків дальнього радіолокаційного виявлення й управління Е-2C та здійснювали пуски ракет 3

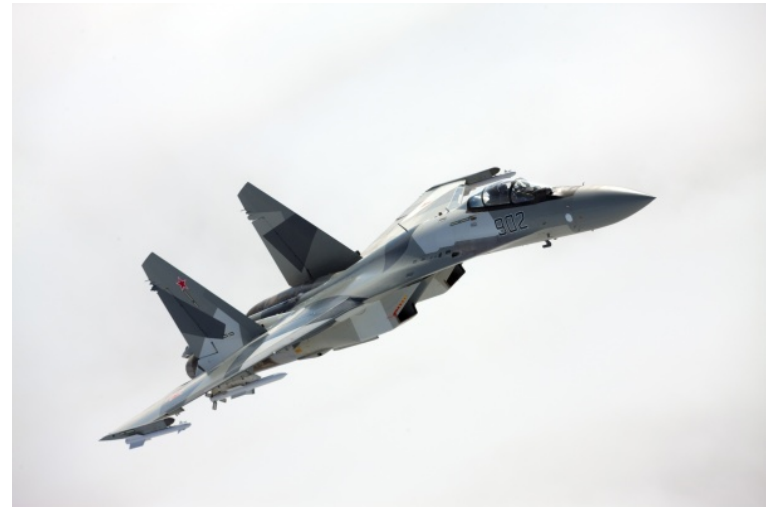

Pис. 7. Су-35C.

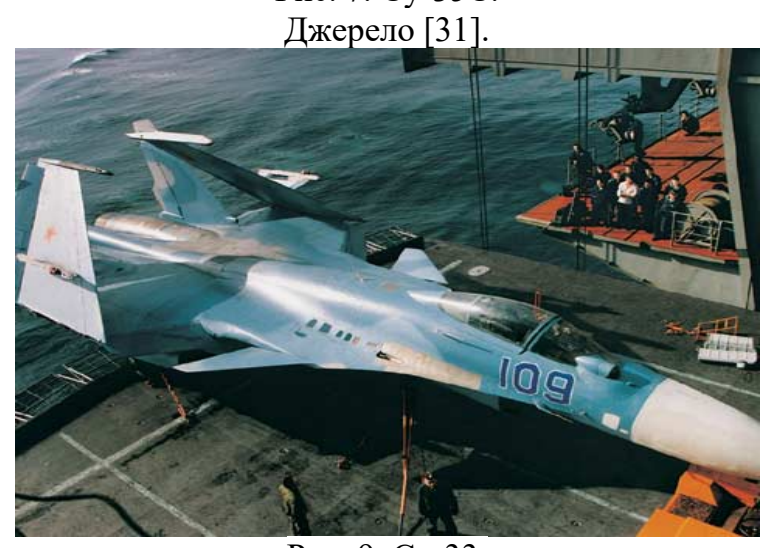

Рис. 9. Су-33.

Джерело [29].

середньої і великої дальності, перемога зазвичай була на боці ізраїльтян [34, с. 83].

Незважаючи на свої переваги, машини 4-го покоління мали й певні недоліки. Серед них варто відзначити високу помітність для інфрачервоних та радіолокаційних прицільних систем через особливості конструкції та розміщення авіаційних засобів ураження на зовнішніх вузлах підвіски і крейсерську дозвукову швидкість та необхідність вмикання форсажу для підвищення швидкості на короткий час. Підвищення тактико-технічних характеристик літаків цього покоління відбувалось шляхом модернізації до рівня 4+ та 4++. У цьому процесі відбувалось вдосконалення бортового радіоелектронного обладнання, розширення номенклатури авіаційних засобів ураження, підвищення універсальності шляхом надання винищувачам спроможностей уражати цілі на поверхні тощо. Проте, це не надавало даним машинам принципово нових властивостей. Деякі бойові машини, наприклад доволі вдалий палубний багатоцільовий винищувач F/A-18 Hornet [4] за своєю швидкістю навіть поступався літакам 3-го покоління, що у повітряному бою могло мати фатальні наслідки. Отже, незважаючи на те, що бойові машини 4-го покоління стали однозначним кроком вперед, наприкінці XX століття виникли потреби у нових бойових 
літаках, 3 принципово іншими бойовими властивостями.

У 1980-х роках в ряді країн, перш за все у США та СРСР, воєнно-політичне керівництво дійшло думки про необхідність розроблення принципово інших літаків тактичної авіації, що, поряд 3 характеристиками бойових літаків 4-го покоління, будуть володіти спроможністю здійснювати тривалий політ 3 високою надзвуковою швидкістю, відрізнятимуться малою помітністю для радіолокаційних та інфрачервоних сенсорів завдяки використанню технологіï Stealth, одержать значно кращі маневрені характеристики зі спроможністю всеракурсного застосування авіаційних засобів ураження, перш за все високоточних. При цьому за своїм призначенням ці машини будуть багатофункціональними, здатними однаково успішно боротись як з повітряним противником, так і наземним (морським). Розглядались варіанти створення важкого i легкого багатофункціонального винищувача, проте реальні здобутки дещо відрізнялись від планів.

Так, у США першою спробою реалізації такого підходу став тактичний винищувач, а фактично - винищувач - бомбардувальник Lockheed F-117 Night Hawk. Дійсно, реалізація технологій Stealth сприяла зменшенню дальності виявлення літака засобами ППО, проте решта тактико-технічних характеристик (низька швидкість, мале корисне навантаження, погані маневрені характеристики тощо) дозволяли застосовувати такий літак лише проти слабкого противника із застарілою системою ППО, як це мало місце в Іраку (1991 р.) та Югославії (1999 р.). При цьому вартість одного літака суттєво перевищувала цей показник для серійних тактичних винищувачів, що перебували на озброєнні ВПС та ВМС США. Після нетривалої експлуатації природним стало рішення про припинення їх виробництва та зняття з озброєння [12]. Незважаючи на доволі посередні тактикотехнічні характеристики, слід віддати належне американським розробникам, яким вдалось відпрацювати серійне виробництво бойових літаків, побудованих з використанням технологій Stealth та вирішити проблему управління літальним апаратом із вкрай невдалою аеродинамікою.

Більш вдалою спробою створити повноцінну машину 5-го покоління слід вважати американський винищувач Lockheed/Boeing F-22 Raptor. Багатоцільовий винищувач завоювання панування у повітрі відрізнявся високими льотнотехнічними характеристиками, зокрема маневреністю, що забезпечувалась двигунами 3 відхиленням вектору тяги у вертикальній площині, високою тактичною обізнаністю завдяки потужному прицільно-навігаційному комплексу, здатністю до роботи в мережевоцентричній системі управління збройною боротьбою тощо [7]. До недоліків варто віднести високу вартість одного літака (до 345 млн. дол. США) та експлуатаційні витрати (вартість однієї години польоту майже удвічі перевищувала аналогічний показник для F-15) при неочевидних перевагах перед останнім, доволі скромний боєкомплект [17]. За маневреністю F-22 поступався винищувачам РФ покоління 4+ Су-30СМ та 4++ Су-35С, також оснащеним двигунами 3 відхиленням вектору тяги у двох площинах. При цьому російські машини, при значно меншій вартості, наприкінці першого десятиліття XX ст. вийшли на стадію серійного виробництва. В результаті F-22 так і не став масовим винищувачем. Після випуску 184 машин їх виробництво було згорнуто, проте вони досі перебувають на озброєнні ВПС США [9].

Черговою спробою створити масовий літак 5-го покоління стала програма JSF (англ. Joint Strike Fighter - єдиний ударний винищувач), в рамках якої передбачалося створення лінійки літаків для ВПС, палубної авіації та авіації Корпусу морської піхоти США, що була прийнята на озброєння під індексом F-35 Lightning II. Планувалося, що нова машина стане масовим багатофункціональним літаком, який зможе успішно вести повітряні бої та уражати наземні (морські) цілі, прориваючи систему ППО противника зокрема й завдяки малій помітності. Проте, реалізувати замисел повністю, на нашу думку, розробникам не вдалося. Дійсно, завдяки наявності підйомного двигуна F-35 має хороші злітно-посадкові та маневрені характеристики, особливо на малих висотах, сучасне БРЕО, здатний здійснювати інформаційний обмін 3 іншими літаками, пунктами управління та безпілотними літальними апаратами, проте машина має ряд суттєвих недоліків - літак, оснащений одним двигуном, тим самим Pratt \& Whitney F135, що застосовувався на F-22. Водночас його швидкість (максимальна - менше 2000 км/год.) не дозволяють протистояти навіть менш сучасним винищувачам, він не має можливості здійснювати політ 3 крейсерською дозвуковою швидкістю, поступається за маневреністю літакам 4-го покоління, а вартість більше 90 млн. дол.. за одиницю аж ніяк не сприяє масовому виробництву, не говорячи вже про вартість експлуатації [2]. Водночас, незважаючи на ці недоліки, F-35 прийнятий на озброєння, виробляється серійно і освоюється у 
військах кількох країн. Проте, реально оцінити бойову ефективність американських винищувачів 5-го покоління поки що доволі важко, адже досвіду їх застосування у воєнному конфлікті в умовах наявності у противника сучасної ППО та винищувальної авіації на сьогодні немає.

$$
\text { Роботи щодо створення }
$$

багатофункціональних винищувачів відбувались і в інших країнах. Так, у 1979 році розпочалось створення важкого багатофункціонального винищувача в ОКБ ім. А.І. Мікояна. Розроблявся винищувач, оснащений двома інноваційними двигунами АЛ-41, яких на той час ще не було, 3 розміщенням авіаційних засобів ураження всередині фюзеляжу, 3 крейсерською надзвуковою швидкістю без увімкнення форсажу та здатністю до керованого польоту на закритичних кутах атаки. За різними джерелами максимальна швидкість нової машини мала дорівнювати від 2500 до 3000 км/год на великій висоті. Проте, розпад СРСР суттєво загальмував роботи i, незважаючи на те, що виріб 1.44 здійснив перший політ у 2000 році, він залишився єдиним, а програма була припинена [18].

Більшого успіху вдалося досягти колективу ОКБ ім. П.Й. Сухого вже у пострадянський період. У 2010 році здійснив перший політ багатофункціональний винищувач Т-50, прийнятий пізніше на озброєння повітрянокосмічних сил РФ як Су-57. За інформацією 3 відкритих джерел ця машина повністю задовольняючи вимогам до багатофункціональних винищувачів 5-го покоління, відрізняється значно меншою вартістю, на рівні винищувачів покоління 4+. Проте, автори обережно ставляться до цієї інформації, адже станом на сьогодні підтверджень їі вірогідності із незалежних джерел немає: машина не виробляється масово, контракт, укладений міністерством оборони РФ 3 промисловістю, передбачає постачання у війська до 2028 року менше 80 літаків, що дозволить озброїти до двох полків, даних про бойове застосування Су-57 у реальних умовах немає [15]. На відміну від російської машини, американські аналоги хоча б надійшли на озброєння i експлуатуються у військах. Про Су-57 цього сказати поки що не можна, тому й судити про його реальні характеристики доволі складно.

Заслуговує певної уваги інформація про легкий багатофункціональний винищувач 5-го покоління, відомий як Су-75 Checkmate. Ця експериментальна розробка легкого багатофункціонального винищувача упродовж останнього року неодноразово демонструвалась на міжнародних виставках озброєння і військової техніки. Відповідаючи, за словами представників ОКБ ім. П.Й. Сухого, вимогам до 5-го покоління, Су-75 вигідно відрізняється економічними показниками закупівлі та експлуатації, зокрема завдяки наявності одного двигуна, за яким він уніфікований з Су-57. Ця машина розроблялась в ініціативному порядку, існує лише у вигляді прототипу, який не здійснив жодного польоту [27]. Проте, авіаційне виробниче об'єднання ім. Ю.О. Гагаріна в Комсомольську-на-Амурі вже приступило до будівництва передсерійної партії і можна очікувати скорого початку їх випробувань [25]. Водночас, як i про Су-57, обгрунтовано судити про реальні бойові та експлуатаційні характеристики поки що передчасно, а орієнтуватись у цьому на висловлювання його розробників, на думку авторів, не варто.

Роботи щодо створення бойових машин 5-го покоління активно проводять і китайські авіабудівельники. У 2017 році на озброєння військово-повітряних сил Народно-визвольної армії Китаю був прийнятий новітній винищувач J-20, створений авіабудівельною корпорацією Chengdu Aircraft Industry Corporation [19]. Незважаючи на відповідність окремим ознакам 5-го покоління, J-20 має традиційну для китайської авіаційної промисловості проблему 3 двигунами, що не можуть забезпечити новій машині потрібну швидкість і тягоозброєність. Проте, за економічними показниками, що також традиційно для воєнно-технічної продукції Китаю, цей літак можна вважати одним із кращих у своєму класі, крім того, машина прийнята на озброєння і ритмічно надходить у війська [3].

Отже, можна констатувати, що, незважаючи на окремі досягнуті успіхи, жодна країна на сьогодні не спромоглася створити повноцінний багатофункціональний винищувач 5-го покоління, про який можна стверджувати, що він відповідає всім вимогам до таких бойових машин. Роботи у цьому напрямі тривають і можна очікувати, що упродовж найближчого десятиліття вони призведуть до очікуваних результатів, принаймні в США, Росії та Китаї.

Однак, проблеми, пов'язані 3 потребою оновлення літакового парку ВПС, актуальні на сьогодні для всіх країн, адже винищувачі 4-го покоління, що виготовлялись до 1990-х років вичерпали свій призначений ресурс, а ускладнення повітряної обстановки вимагає більш досконалих бойових машин і у достатній кількості. Основним напрямом розв'язання цієї проблеми у провідних країнах світу є подальша модернізація машин покоління 4+ та 4++. Такі роботи проводяться європейськими виробниками щодо винищувачів Eurofighter Typhoon 
(Великобританія, Німеччина, Франція, Італія, Іспанія), Dassault Rafale (Франція), SAAB JAS 39 (Швеція). Не менш активно ведуться роботи в США щодо модернізації таки машин, як F-16, F/A-18, F-15. В Росії тривають роботи над новітньою машиною МиГ-35, що $є$ розвитком багатофункціональної версії легкого винищувача МиГ-29. Оголошено про черговий етап модернізації багатофункціональних винищувачів лінійки Су-30 шляхом уніфікації їх за двигуном та прицільно-навігаційним комплексом 3 Су-35C $[20]$.

\section{Висновки}

Враховуючи проблеми старіння літакового парку авіації Повітряних Сил ЗС України та його чисельність, для нас проблема його оновлення стає надзвичайно актуальною і ця актуальність зростає щороку, набуваючи характеру реальної загрози, особливо, якщо враховувати поточну воєнно-політичну обстановку. За даними британського видання Flight International, у бойовому складі української авіації на сьогодні перебувають 26 винищувачів Су-27, 16 МиГ-29, 12 бомбардувальників Су-24М і 13 штурмовиків Су-25 [16]. Відсутність власного виробництва ударних літаків та перспектив щодо його появи ставить питання про імпорт необхідних машин, 3 перспективою, що було б державницьким рішенням, ї ліцензійного виробництва на вітчизняних підприємствах, хай навіть 3 мінімальною локалізацією на перші роки.
На наш погляд, за сукупністю тактико-технічних характеристик та 3 міркувань спрощення освоєння нових машин льотним та інженернотехнічним складом і організації експлуатації у військах, а також за вартістю найбільш раціональним рішенням було би звернення уваги на машини сімейства Су-30. Проте, в сучасних умовах i у середньостроковій перспективі це неможливо. На нашу думку, варто розглянути питання щодо можливості оснащення вітчизняної авіації останніми версіями пари важкий - легкий винищувач: багатофункціональний важкий двомісний F-15EX та легкий F-16 Block 60. Прийняття такого рішення дозволить:

значно підвищити бойові спроможності вітчизняної авіації;

зменшити кількість типів літальних апаратів; забезпечити необхідну тактичну i оперативну гнучкість у застосуванні авіації.

Такий шлях $\epsilon$ дуже затратним, це потребуватиме не лише закупівлі авіаційної техніки, озброєння, запасних блоків, вузлів та агрегатів i засобів наземного забезпечення польотів, але й адаптації всієї авіаційної інфраструктури до принципово іншої іноземної техніки, витрати значних ресурсів для перенавчання особового складу. Проте, альтернативою такому шляху $\epsilon$ повна утрата вітчизняної авіації як складової збройних сил, що абсолютно неприпустимо для будь-якої держави у сучасних умовах.

\section{Список літератури}

1. Boeing - [Електрон. Ресурс]. - Режим доступу: https:// www.boeing.com.

2. Carlo Kopp. Assessing Joint Strike Fighter Defence Penetration Capabilities. //Air Power Australia.. - [Електронний pecypc] - Режим доступу: http:// www.ausairpower.net/APA-2009-01-Annex.html.

3. Chengdu J-20.China's 5th Generation Fighter.// Defense Update. - [Електронний ресурс] - Режим доступу: http:// www.defense-update.com/products/j/29122010_j-20.html.

4. F/A-18 HornetFighter // Boeing. - [Електронний pecypc] - Режим доступу: https://www.boeing.com/history/products/fa18-hornet.page.

5. F-15 Eagle tactical fighter// Boeing. - [Електронний ресурс] - Режим доступу: http://www.boeing.com/history/products/f15-eagle.page.

6. f-16 fighting falcon // Lockheed Martin. - [Електронний ресурс] - Режим доступу: https://www.lockheedmartin.com/enus/news/features/history/f16.html.

7. F-22 RaptorSpecifications // Global security. - [Електронний ресурс] - Режим доступу: https://www.globalsecurity.org/military/systems/aircraft/f-22-specs.htm.

8. F-4B (F4H-1) Phantom II. // Уголок неба. Авиационная энциклопедия. - [Електронний ресурс] - Режим доступу: http://www.airwar.ru/enc/fighter/f4b.html.

9. Final Raptor Rolls Out // Code one archive. .- [Електронний ресурс] - Режим доступу: http://www.codeonemagazine.com/news_item.html?item_id=526.

10. Lockheed Martin .- [Електронний ресурс] - Режим доступу: https://www.lockheedmartin.com.

11. TheF-15 satellite killer and the ASM-135AASATmissile .- [Електронний ресурс] - Режим доступу: URL:https://theaviationgeekclub.com/f-15-satellite-killer-asm-135a-asat-missile. 
12. Американский боевой самолет Lockheed F-117 Nighthawk // MILITARY ARMS. RU. .- [Електронний ресурс] Режим доступу: https://militaryarms.ru/voennaya-texnika/aviaciya/boevoj-samolet-lockheed-f-117-nighthawk/.

13. Бабич В. К. Истребители меняют тактику.// Санкт-Петебургская Авиа Школа. .- [Електронний ресурс] - Режим доступу: http://lockon.spb.ru/babich_fighters.html.

14. Бабич В.К. Истребители меняют тактику. - М.: Воениздат, 1983. - 151 с.

15. Борисов сообщил об итогах испытаний истребителя Су-57 // РИА Новости. .- [Електронний ресурс] - Режим доступу: https://ria.ru/20200521/1571760348.html.

16. Воробьев В. Воздушные Силы Украины в 2021 году // AeroVokzal. - [Електронний ресурс] - Режим доступу: https://aerovokzal.net/vozdushnye-sily-ukrainy-v-2021-godu/.

17. Гэппер Джон. Американские ВВС бьют мимо цели // Иносми. - [Електронний ресурс] - Режим доступу: https://inosmi.ru/world/20080717/242649.html.

18. Ильин В. Многофункциональный фронтовой истребитель - МФИ // Военная теника России. - [Електронний pecypc] - Режим доступу: http://www.milrus.com/vvs/mig39/text.shtml.

19. Китайский новейший истребитель J-20 совершил показательный полет // Российская газета. - [Електронний ресурс] - Режим доступу: https://rg.ru/2016/11/01/kitajskij-novejshij-istrebitel-j-20-sovershil-pokazatelnyj-polet.html.

20. Лавров А., Рамм А. Капитальный апгрейд: Минобороны начало обновление Су-30СМ. Какие возможности обретут "Супер-Сухие" после капремонта // Известия. ru. - [Електронний ресурс] - Режим доступу: https://iz.ru/1201176/anton-lavrov-aleksei-ramm/kapitalnyi-apgreid-minoborony-nachalo-obnovlenie-su-30sm.

21. МиГ-29/МиГ-29УБ/МиГ-29СЭ // Российская самолетостроительная корпорация МиГ. - [Електронний ресурс] Режим доступу: http://www.migavia.ru/index.php/ru/produktsiya/semejstvo-istrebitelej-mig-29/mig-29-mig-29ub-mig-29se.

22. Многоцелевой истребитель Су-27: история, устройство и ТTX // Militaryarms.ru. Военный обзор. - [Електронний pecyрc] - Режим доступу: https://militaryarms.ru/voennaya-texnika/aviaciya/su-27/.

23. Многоцелевой истребитель-бомбардировщик Су-30 // Армии и солдаты. Военная энциклопедия. - [Електронний ресурс] - Режим доступу: http://armedman.ru/samoletyi/1991-2015-samoletyi/mnogotselevoy-istrebitel-bombardirovshhik-su-30.html.

24. Позняков П., Титков С, Рдиолокатор - это еще не все на истребителе / Радиоэлектронные технологии, 2015. № 3. - С. 96-98.

25. Постройка сразу нескольких перспективных истребителей Checkmate началась в Комсомольске-на-Амуре // Военное обозрение. [Електронний ресурс] - Режим доступу: https://topwar.ru/189103-postrojka-srazu-neskolkihperspektivnyh-istrebitelej-checkmate-nachalas-v-komsomolske-na-amure.html.

26. Пятое поколение боевой авиаии: перспектива или тупик? // AVIA.RU.NETWORK. - [Електронний ресурс] Режим доступу: https://www.aviaru.net/author/generation5/.

27. Разработчики раскрыли данные о новом российском истребителе “Шах и мат" // РБК. - [Електронний ресурс] Режим доступу: https://www.rbc.ru/business/20/07/2021/60f685f09a7947e022c0a7d7.

28. Российская самолетостроительная корпорация МиГ. - [Електронний ресурс] - Режим доступу: http://www.migavia.ru.

29. Су-33 // СУХОЙ. - [Електронний ресурс] - Режим доступу: https://www.sukhoi.org/products/earlier/255/.

30. Су-34 // СУХОЙ. - [Електронний ресурс] - Режим доступу: https://www.sukhoi.org/products/samolety/254/.

31. Су-35 // СУХОЙ. - [Електронний ресурс] - Режим доступу: https://www.sukhoi.org/products/samolety/256/.

32. Сухой - [Електронний ресурс] - Режим доступу: https://www.sukhoi.org.

33. У России появятся противоспутниковые ракеты // RUPOSTERS - [Електронний ресурс] - Режим доступу: https://ruposters.ru/news/26-10-2018/protivosputnikovie-raketi

34. Харук А. Боевая авиация XXI века. Цветное коллекционное издание. - М. Издательство "Эксмо", 2011, - 304 с.

35. Харук А. ВВС ХХІ века. Цветное коллекционное издание. - М. Издательство "Эксмо", 2013, - 304 с.

\section{Відомості про авторів:}

\section{Рєзнік Володимир Ігорович}

кандидат історичних наук старший науковий співробітник професор кафедри управління військами Національного університету оборони України імені Івана Черняховського,

м. Київ, Україна

Researcher ID AAY-4622-2020

https://orcid.org/0000-0003-1479-4852

\section{Information about the authors:}

\section{Volodimir Reznik}

Candidate of Historical Sciences

Senior Researcher

Professor of Troop management Department

of National Defence University of Ukraine

named after Ivan Cherniakhovskyi,

Kyiv, Ukraine

Researcher ID AAY-4622-2020

https://orcid.org/0000-0003-1479-4852 


\section{Постольник Микола Миколайович}

викладач кафедри Сухопутних військ Національного університету оборони України імені Івана Черняховського,

м. Київ, Україна

ttps://orcid.org/0000-0002-9544-0468

\section{Мосолов Василь Миколайович}

старший викладач кафедри оперативного мистецтва Національного університету оборони України імені Івана Черняховського, м. Київ, Україна https://orcid.org/0000-0003-3974-8182

\section{Сторожук Сергій Миколайович}

старший науковий співробітник

Державного науково-дослідного інституту авіації, Київ, Україна

https://orcid.org/0000-0001-5271-0272

\section{Mykola Postolnik}

Lecture of Land Forces Department of National Defence University of Ukraine named after Ivan Cherniakhovskyi, Kyiv, Ukraine https://orcid.org/0000-0002-9544-0468

\section{Vasyl Mosolov}

Senior Lecture of Operative Art Department of National Defence University of Ukraine named after Ivan Cherniakhovskyi, Kyiv, Ukraine https://orcid.org/0000-0003-3974-8182

\section{Serhii Storozhuk}

Senior Researcher of State Research Institute of Aviation, Kyiv, Ukraine https://orcid.org/0000-0001-5271-0272

\title{
FOURTH AND FIFTH GENERATION AVIATION EQUIPMENT: HISTORY AND DIRECTIONS OF FURTHER DEVELOPMENT
}

\author{
V. Reznik, M. Postolnik, V. Mosolov, S. Storozhuk
}

The article considers the processes of origin and development of tactical aviation of the fourth and fifth generations. The reasons that led to its emergence, characteristics and differences are highlighted. One of the reasons for the development of 4th generation fighters was the experience of using aircraft during the Korean War. A characteristic feature of aviation equipment that began to be developed after this war was the integration of various information and executive devices and systems on board the aircraft carrier in the onboard sighting and navigation complex. The latter began to include information sensors of various natures, such as stationary on-board radar stations capable of operating on both air and ground targets and optoelectronic stations. The latter from the beginning included laser rangefinders, and later - and full-fledged laser-television sighting systems.

The strengths and weaknesses of tactical fighters of different generations are considered, their comparative analysis is carried out. It is shown that the main players who set the tone among the aircraft design bureaus were representatives of only 2 countries: USSR and USA.

The authors conclude that the world's fifth-generation multi-role fighters are currently not fully meeting the needs of the Air Force due to incomplete compliance with tactical requirements and economic considerations. The directions of further development of the fourth generation aviation equipment, which has not exhausted its modernization potential and is able to meet modern requirements in the medium term, are determined. At the end of the article, proposals are made on possible directions for updating the tactical aircraft fleet of the Air Force of the Armed Forces of Ukraine.

Keywords: tactical aviation, multifunctional fighter, Stealth technology, generation of fighters, over-maneuverability, modernization. 